\title{
PENGARUH JUMLAH KASUS HIV/AIDS DAN CAKUPAN RUMAH SEHAT TERHADAP JUMLAH KASUS TUBERKULOSIS DI PROVINSI JAWA TIMUR
}

\author{
Rosalia Nur Hakim \\ Departemen Biostatistika dan Kependudukan \\ Fakultas Kesehatan Masyarakat Universitas Airlangga \\ Jl. Mulyorejo Kampus C Unair Surabaya 601115, \\ Alamat Korespondensi: Rosalia Nur Hakim \\ E-mail: rosalianurhakim8@gmail.com
}

\begin{abstract}
Tuberculosis is a disease caused by bacterial infection of Mycobacterium tuberculosis that can be transmitted from the patient to the surrounding environment including humans, which attacks the lung organ and other organs in the body. Based on the epidemiological triangle, infectious diseases are caused by 3 factors such as agent factor, host and environment. One of the host factors of Tuberculosis is HIV/AIDS, where many Tuberculosis infections are common in people with HIV/AIDS. From environmental factors causing Tuberculosis disease is a condition of less healthy house. Tuberculosis incidence in East Java Province in 2015 amounted to 44,063 which increased from 2014 that is as much as 42,475. This research was conducted to analyze the influence between HIV/AIDS and healthy house case against Tuberculosis incident in East Java Province. This research is a kind of analytical research using non-reactive method. The research sample used is total population consist of 29 regencies and 9 cities in East Java Province. Technical analysis of the research using multiple linear regression test. The results showed that there was a significant influence between HIV/AIDS cases on Tuberculosis occurrence in East Java ( $p$-value =0,000), and there was no significant influence between healthy house on Tuberculosis incidence in East Java Province. The conclusion of this study is that there is a significant relationship between HIV/AIDS cases and Tuberculosis cases in East Java Province. The HIV / AIDS and tuberculosis cases in East Java need to be improved by the Provincial Government of East Java such as providing information related to HIV/AIDS and Tuberculosis and screening HIV/AIDS.
\end{abstract}

Keywords: tuberculosis, HIV/AIDS, healthy house

\begin{abstract}
ABSTRAK
Tuberkulosis merupakan penyakit yang diakibatkan karena infeksi bakteri Mycobacterium tuberculosis yang dapat menular dari penderita ke lingkungan yang ada disekitarnya termasuk manusia, yang menyerang organ paru dan organ lain pada tubuh. Berdasarkan segitiga epidemiologi, penyakit menular disebabkan oleh 3 faktor antara lain faktor agent, host dan environment. Salah satu faktor host dari penyakit Tuberkulosis adalah HIV/AIDS, dimana banyak infeksi Tuberkulosis yang sering terjadi adalah pada penderita HIV/AIDS. Dari faktor lingkungan yang menyebabkan penyakit Tuberkulosis adalah kondisi rumah yang kurang sehat. Kejadian Tuberkulosis di Provinsi Jawa Timur pada tahun 2015 berjumlah 44.063 yang meningkat dari tahun 2014 yaitu sebanyak 42.475. Penelitian ini dilakukan untuk menganalisis adanya pengaruh antara kasus HIV/AIDS dan rumah sehat terhadap kejadian Tuberkulosis di Provinsi Jawa Timur. Penelitian ini merupakan jenis penelitian analitik yang menggunakan metode non-reactive. Sampel penelitian yang digunakan adalah total populasi yang terdiri dari 29 kabupaten dan 9 kota di Provinsi Jawa Timur. Teknis analisis penelitian menggunakan uji regresi linier berganda. Hasil penelitian menunjukkan bahwa terdapat pengaruh yang signifikan antara antara kasus HIV/AIDS terhadap kejadian Tuberkulosis di Provinsi Jawa Timur $(p$-value $=0,000)$, dan tidak ada pengaruh yang signifikan antara rumah sehat terhadap kejadian Tuberkulosis di Provinsi Jawa Timur. Kesimpulan dari penelitian ini yaitu terdapat hubungan yang signifikan antara kasus HIV/AIDS dengan kasus Tuberkulosis di Provinsi Jawa Timur. Program penanggulangan kasus HIV/AIDS dan tubekulosis di Provinsi Jawa Timur perlu ditingkatkan oleh Pemerintah Provinsi Jawa Timur seperti melakukan pemberian informasi terkait HIV/AIDS dan Tuberkulosis serta melakukan skrinning HIV/AIDS.
\end{abstract}

Kata kunci: tuberkulosis, HIV/AIDS, rumah sehat 


\section{PENDAHULUAN}

Penyakit Tuberkulosis menjadi target utama penanggulangan masalah kesehatan masyarakat, karena dampaknya yang masih menimbulkan kesakitan, kecacatan dan kematian yang tinggi. Menurut Najmah (2016) penyebab kematian tertinggi di dunia disebabkan oleh Tuberkulosis, setelah Human Immunodeficiency Virus (HIV). Pemerintah Indonesia telah melakukan berbagai program penanggulangan untuk Tuberkulosis, namun sampai sekarang penyakit ini masih banyak menimbulkan dampak bagi masyarakat. Hal ini didukung dengan adanya program penanggulangan Tuberkulosis nasional yang ditargetkan dapat mengeliminasi Tuberkulosis pada tahun 2035 dan Indonesia tidak lagi memiliki kasus Tuberkulosis pada tahun 2050 . Strategi pemerintah nasional terkait penanggulangan Tuberkulosis yang tercantum dalam PMK nomor 67 Tahun 2016 tentang Penanggulangan Tuberkulosis antara lain adalah menstabilkan manajemen program, meningkatkan akses ke tempat pelayanan dan kemitraan TB, mengendalikan penyebab yang dapat meningkatkan risiko $\mathrm{TB}$, peningkatan kemampuan masyarakat dalam menanggulangi TB secara mandiri, dan memperkuat kepemimpinan program TB.

Jumlah kasus tuberkulosis yang ditemukan di Indonesia sebanyak 351.893 kasus pada tahun 2016. Bila dibandingkan dengan total kasus tuberkulosis yang terjadi pada tahun 2015 sebesar 330.910 kasus, jumlah kasus pada tahun 2016 telah mengalami peningkatan. Angka notifikasi seluruh kasus tuberkulosis pada tahun 2015 sebesar 130 per 100.000 penduduk juga mengalami peningkatan jika dibandingkan tahun 2014 yakni sebesar 129 per 100.000 penduduk. Provinsi dengan total kejadian tuberkulosis tertinggi di Indonesia yang pertama adalah Provinsi Jawa Barat, yang kedua yakni Jawa Timur dan selanjutnya diduduki oleh Jawa Tengah. Hasil cakupan penemuan kasus penyakit Tuberkulosis pada tahun 2016 di Jawa Timur sebesar 48.808 kasus yang menempati posisi kedua penemuan kasus Tuberkulosis terbesar setelah Jawa Barat (Kemenkes RI, 2017).

Pengendalian faktor risiko dari penyakit Tuberkulosis dapat dilaksanakan jika faktorfaktor yang mempengaruhi penyakit Tuberkulosis dapat diketahui. Berdasarkan konsep penyebab penyakit menular yaitu segitiga epidemiologi, penyakit menular disebabkan oleh 3 faktor yakni external agent, susceptible host dan environment.

Faktor agent yang menjadi penyebab penyakit Tuberkulosis ini merupakan Mycobacterium tuberberculosis. Kuman ini memiliki bentuk batang yang digolongkan dalam basil asam (BTA), tipis, kecil, sedikit bengkok, memiliki granula dan hidupnya berpasangan yang hanya bisa dilihat dengan menggunakan mikroskop (Najmah, 2016). Kuman ini dapat bertahan di dalam suhu rendah pada suhu $4^{\circ} \mathrm{C}$ sampai minus $70^{\circ} \mathrm{C}$ dalam waktu yang cukup lama. Kuman akan mati ketika mendapatkan paparan sinar secara langsung, karena kuman Tuberkulosis ini sangat sensitif dengan adanya panas, baik panas dari sinar matahari maupun sinar ultraviolet. Kuman Tuberkulosis pada dahak akan mati setelah berada pada suhu $30-37^{\circ} \mathrm{C}$ selama kurang lebih 1 minggu. Serta kuman ini memiliki sifat dapat melakukan "tidur" atau dormant atau tidak berkembang di dalam jaringan tubuh dalam periode yang lama, bahkan bisa sampai beberapa tahun (Kemenkes RI, 2014).

Faktor host/penjamu yang merupakan semua faktor yang dimiliki dalam diri manusia, dimana faktor tersebut dapat menimbulkan suatu penyakit, seperti genetik, imunitas, usia, dan jenis kelamin. Salah satu host yang berisiko terkena penyakit Tuberkulosis yakni penderita HIV/AIDS. Kerusakan sistem kekebalan tubuh yang ditimbulkan oleh infeksi HIV menyebabkan adanya infeksi oportunistik, seperti Tuberkulosis. Orang yang terinfeksi HIV memiliki risiko 26-31 kali terserang penyakit Tuberkulosis (Najmah, 2016). Epidemi HIV memiliki pengaruh terhadap peningkatan epidemi Tuberkulosis di seluruh dunia, dan berdampak pada meningkatnya jumlah kasus Tuberkulosis di masyarakat (Karima, et.al., 2017).

Faktor lingkungan yang dapat menyebabkan penyakit Tuberkulosis dibedakan menjadi 3 jenis, yaitu lingkungan fisik, lingkungan biologi, dan lingkungan sosial. Faktor lingkungan fisik seperti air, udara, tanah, makanan, panas, radiasi merupakan faktor yang berpengaruh pada penularan penyakit karena sifatnya yang tidak hidup atau abiotik. Berdasarkan Ditjen PPM dan PL (2002) sanitasi rumah yang tidak sehat yang menjadi salah satu faktor penyebab kejadian penyakit Tuberkulosis maupun 
penyakit ISPA. Rumah yang tidak sehat bisa menjadi faktor risiko terjadinya sumber penularan penyakit yang dilihat dari faktor lingkungannya (Keman, 2005). Perilaku penghuni rumah yang kurang sehat juga dapat memicu perkembangan penyakit (Sukarni, 1995). Departemen Kesehatan RI telah melaksanakan program untuk meningkatkan kualitas lingkungan agar dapat mengurangi risiko terjadinya penyakit atau gangguan kesehatan, salah satu indikator yang dinilai adalah rumah sehat. Komponen penilaian dari rumah sehat terdiri dari komponen rumah, sarana sanitasi, dan perilaku antara lain yakni kepemilikan TPS, saluran PAL, sarana air bersih, sirkulasi udara yang baik, jamban yang sehat, tempat tinggal memiliki kepadatan yang sesuai dan kondisi lantai hunian (Dinkes Provinsi Jawa Timur, 2016). Sedangkan pada lingkungan biologi berkaitan dengan segala makhluk hidup yang terdapat di lingkungan hidup host yang menyebabkan penyakit Tuberkulosis. Menurut Mukono (2006) terdapat hubungan antara lingkungan biologi dengan penyakit yakni sebagai agent penyakit yang infeksius, reservoir, vector pembawa penyakit, maupun sebagai tumbuhan dan binatang. Jenis lingkungan sosial merupakan faktor kehidupan sosial sekitar yang dimiliki oleh host yang dapat meningkatkan risiko untuk penyebaran penyakit.

Tujuan dari penelitian ini adalah menganalisis pengaruh HIV/AIDS sebagai varibel independen dari faktor host/pejamu dan rumah sehat sebagai variabel independen dari faktor lingkungan terhadap jumlah kasus Tuberkulosis di Provinsi Jawa Timur sebagai variabel dependen, dengan menggunakan uji regresi linier berganda.

\section{METODE PENELITIAN}

Jenis penelitian ini adalah penelitian analitik dengan menggunakan metode non reactive karena data yang digunakan untuk penelitian ini merupakan data sekunder dan tidak melibatkan secara langsung subjek yang diteliti. Penelitian ini dilakukan dengan menggunakan data dari Dinas Kesehatan Provinsi Jawa Timur yaitu data jumlah kasus Tuberkulosis, data jumlah seluruh kasus HIV/AIDS dan data jumlah cakupan rumah sehat dari 38 kabupaten/kota di Provinsi Jawa Timur pada tahun 2015. Penelitian ini dilaksanakan pada bulan April sampai dengan bulan Mei tahun 2018. Besar sampel dari penelitian ini menggunakan total populasi yakni sebanyak 38 kabupaten/kota terdiri dari 29 kabupaten dan 9 kota di Provinsi Jawa Timur.

Variabel dalam penelitian ini terdiri dari satu variabel dependen yaitu kasus Tuberkulosis dan dua variabel independen yakni terdiri dari kasus HIV/AIDS dan rumah sehat. Teknik analisis data yang digunakan pada penelitian ini adalah uji regresi linier berganda.

\section{HASIL PENELITIAN}

Berdasarkan analisis deskriptif yang dilakukan, didapatkan gambaran distribusi untuk setiap varibel penelitian, dimana pada masing-masing variabel memiliki persentase kasus yang berbeda per daerah. Hasil perhitungan persentase kasus Tuberkulosis per 100 penduduk di setiap kabupaten/kota di Provinsi Jawa Timur menunjukkan bahwa Kota Surabaya, Kabupaten Jember, dan Kabupaten Sidoarjo merupakan daerah dengan jumlah kasus Tuberkulosis terbanyak ketiga di Provinsi Jawa Timur yang dutunjukkan pada gambar 1 dengan jumlah kasus sebesar 48,05, 31,26 dan 22,84 kasus dari 100 penduduk pada masing-masing daerah.

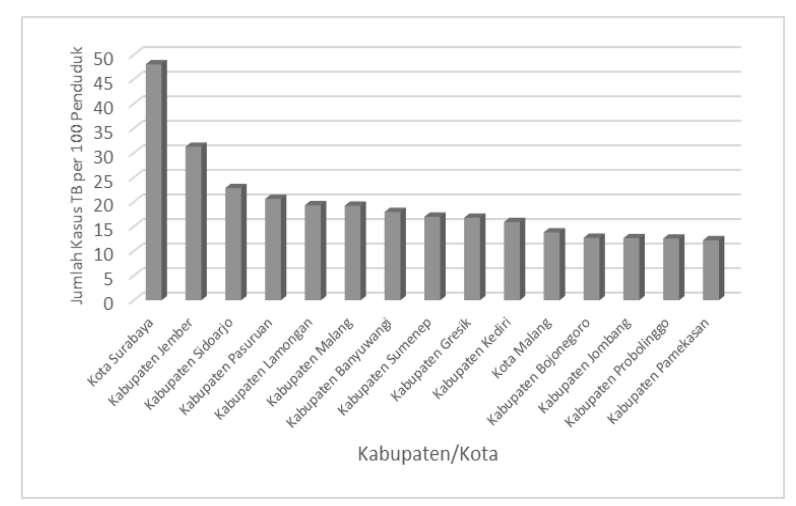

Gambar 1. 15 Kabupaten/Kota dengan Persentase Kasus TB Tertinggi di Provinsi Jawa Timur Tahun 2015

Hasil perhitungan persentase kasus HIV/AIDS per 100 penduduk di setiap kabupaten/kota di Provinsi Jawa Timur yang termuat dalam gambar 2, menunjukkan bahwa Kota Surabaya, Kabupaten Bangkalan, dan Kabupaten Nganjuk memiliki jumlah kasus HIV/AIDS tertinggi ketiga di Provinsi Jawa Timur yakni sebanyak 2,87, 1,43 dan 1,06 
kasus dari 100 penduduk pada masing-masing daerah.

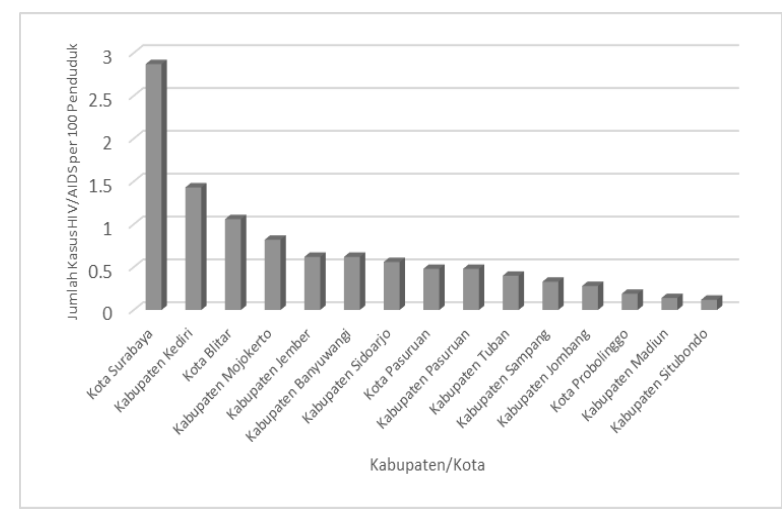

Gambar 2. 15 Kabupaten/Kota dengan Persentase Kasus HIV/AIDS Tertinggi di Provinsi Jawa Timur Tahun 2015

Hasil perhitungan persentase rumah sehat per 100 rumah di setiap kabupaten/kota di Provinsi Jawa Timur seperti pada gambar 3 menunjukkan bahwa Kabupaten Jember, Kabupaten Bangkalan, serta Kabupaten Pacitan memiliki jumlah rumah sehat yang tertinggi ketiga dari 38 Kabupaten/kota di Provinsi Jawa Timur pada tahun 2015 yakni sebanyak 150,61, 93,44 dan 92,71 dari 100 rumah yang ada di masing-masing daerah.

Gambar 1 dan 2 memperlihatkan bahwa beberapa distribusi terjadinya tuberkulosis dan HIV/AIDS pada kabupaten/kota di Provinsi Jawa Timur memiliki persamaan, artinya terdapat kabupaten/kota yang memiliki jumlah HIV/AIDS tinggi juga memiliki jumlah kasus tuberkulosis tinggi, seperti Kota Surabaya, Kabupaten Jember, Sidoarjo, Pasuruan, Banyuwangi, Kediri, Jombang, dan Probolinggo. Hal ini menunjukkan bahwa HIV/AIDS dan tuberkulosis di Provinsi Jawa Timur memiliki hubungan.

Hasil pengujian pengaruh dengan regresi linier berganda didapatkan $p$-value sebesar 0,000 (sig. < 0,05), hal ini berarti bahwa kedua variabel independen yakni HIV/AIDS bersama dengan rumah sehat mempengaruhi kejadian Tuberkulosis di Provinsi Jawa Timur.

Nilai $R$ pada tabel 1 yang didapatkan dari hasil pengujian regresi linier berganda sebesar 0,656, sehingga dapat dilihat bahwa kekuatan hubungan dari variabel independen yaitu HIV/AIDS dan rumah sehat dengan variabel dependen yaitu tuberkulosis tergolong pada kategori kuat. Sedangkan nilai $R^{2}$ sebesar
0,430 mengartikan bahwa kedua variabel HIV dan rumah sehat secara serentak dapat menjelaskan variabel tuberkulosis sebesar $43 \%$.

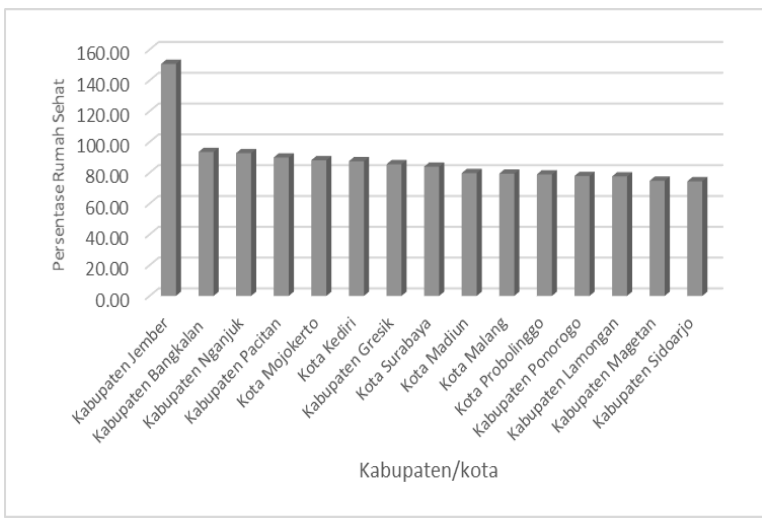

Gambar 3. 15 Kabupaten/Kota dengan Persentase Cakupan Rumah Sehat Tertinggi di Provinsi Jawa Timur Tahun 2015

Gambar 1 dan 3, jika dibandingkan kedua distribusi jumlah tuberkulosis dan rumah sehat juga memiliki pola yang bertolakbelakang dengan kaidah. Artinya terdapat beberapa kabupaten/kota yang memiliki jumlah rumah sehat yang tinggi juga memiliki jumlah tuberkulosis yang tinggi, seperti Kabupaten Jember, Kabupaten Gresik, Kota Surabaya, Kota Malang, Kota Probolinggo, Kabupaten Lamongan, dan Kabupaten Sidoarjo, dimana menurut kaidahnya jika rumah sehat tinggi maka jumlah tuberkulosis semakin rendah. Sehingga, untuk variabel rumah sehat tidak memiliki hubungan terhadap terjadinya tuberkulosis di Provinsi Jawa Timur. Hal ini berbeda dengan penelitian oleh Listyowati (2011) yang menggunakan desain studi kasus case control dengan melakukan observasi. Pengamatan yang dilakukaan untuk menilai kondisi setiap rumah dengan menggunakan instrumen pengamatan yang sudah divalidasi menurut Dirjen PPM dan PL tahun 2002. Hasil penelitian menyatakan bahwa penilaian rumah sehat yang dilakukan berhubungan dengan kejadian tuberkulosis paru dan dapat diketahui perilaku penghuni yang memiliki risiko berhubungan dengan kejadian tubekulosis paru yang diketahui dari 3 kelompok indikator rumah yang sehat. Sehingga kondisi rumah yang sehat dengan didukung perilaku penghuni yang sehat akan bisa menurunkan risiko terkena penyakit tuberkulosis paru karena perilaku dapat mempengaruhi host. Kepekaan 
host terhadap adanya serangan penyakit dapat meningkat atau menurun tergantung pada perilakunya.

Berikut merupakan persamaan regresi yang didapatkan setelah dilakukan pengujian regresi linier berganda:

\section{$\mathrm{TB}=\mathbf{7 , 4 5 3}+\mathbf{1 0 , 5 4 7}(\mathrm{HIV} / \mathrm{AIDS})+\mathbf{0 , 0 1 7}(\mathrm{RS})$}

Nilai intersep dari model yang didapatkan berupa nilai konstanta sebesar 7,453 berarti jika kedua variabel independen dianggap konstan maka nilai Tuberkulosis (TB) sebesar 7,453. Sedangkan nilai koefisian 10,547 artinya setiap kenaikan jumlah HIV/AIDS sebesar 1 satuan maka jumlah Tuberkulosis di Provinsi Jawa Timur mengalami kenaikan sebesar 10,547. Serta nilai koefisien sebesar 0,017 berarti setiap kenaikan jumlah rumah sehat sebesar satu satuan maka jumlah jumlah Tuberkulosis di Provinsi Jawa Timur mengalami kenaikan sebesar 0,017.

\section{Uji Asumsi Regresi}

Uji regresi memiliki 4 asumsi klasik yang harus dipenuhi yaitu asumsi normalitas data, multikolinieritas, heterokedastisitas dan autokorelasi.

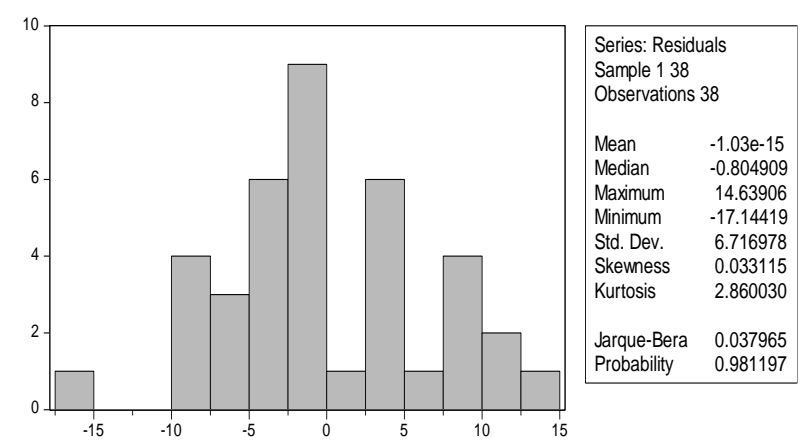

Gambar 4. Output Hasil Jarque-Bera test

Pengujian ini dilakukan untuk mendeteksi distribusi kesalahan nilai sisaan pada model regresi yang didapatkan dari model. Pendekatan Jarque-bera test dapat dilakukan untuk melakukan uji normalitas, dimana model regresi dapat dikatakan berdistribusi normal jika hasil perbandingan dari nilai $\mathrm{J}-\mathrm{B}$ dan $\mathrm{X}^{2}$ tabel menghasilkan nilai J-B hitung kurang dari nilai $X^{2}$ tabel.

Berdasarkan gambar 4 diatas dapat diketahui bahwa distribusi residual dari model adalah normal, dimana ditunjukkan dari nilai Jarque-Bera sebesar 0,037965 yang kurang dari nilai $\mathrm{X}^{2}{ }_{(5 \%)}$ yakni sebesar 90,5312 dan memiliki nilai probabilitas sebesar 0,981197 (sig. $<\alpha=0,05)$.

Uji multikolinieritas dilakukan untuk mengetahui adanya korelasi yang sempurna antara semua variabel independen dari model dengan koefisien korelasi menunjukkan nilai yang tinggi atau bahkan 1. Uji multikolinieritas dapat diuji dengan membandingkan nilai VIF dan tolerance dengan batas yang ditentukan. Hasil uji ini menunjukkan bahwa nilai toleransi terhadap timbulnya kesalahan pada penelitian ini sebesar 0,981, dimana menunjukkan bahwa nilai toleransi lebih besar dari 0,1 dan untuk nilai faktor inflasi simpangan baku kuadratnya sebesar 1,019, dimana nilai tersebut kurang dari batas maksimal yakni sebesar 10, sehingga tidak terjadi multikolinieritas antara variabel HIV/AIDS dengan rumah sehat atau tidak ada hubungan secara linier antara kedua variabel bebas.

Masalah heterokedastisitas merupakan masalah yang didapatkan dari asumsi varian sisaan yang tidak bernilai konstan (Sarwoko, 2005). Pengujian terhadap varian sisaan yang dapat dilakukan dengan melihat penyebaran titik pada grafik scatterplot yang terbentuk.

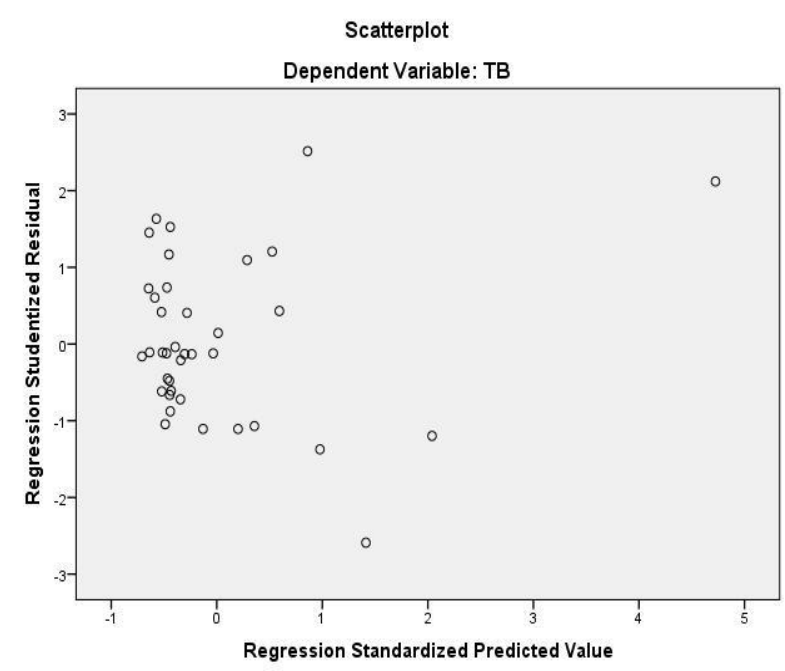

Gambar 5. Grafik Scatterplot Hasil Uji Heterokedastisitas

Gambar 5 menunjukkan bahwa tidak terbentuknya suatu pola yang jelas dalam grafik karena semua titik menyebar disekitar nilai nol, maka tidak terdapat masalah heterokedastisitas, sehingga data dianggap memenuhi syarat. 
Tabel 1. Output Hasil Uji Regresi Linier Berganda

\begin{tabular}{|c|c|c|c|c|c|c|c|c|c|c|}
\hline \multirow[b]{2}{*}{ Model } & \multirow[b]{2}{*}{$\mathbf{R}$} & \multirow[b]{2}{*}{$\begin{array}{c}\mathbf{R} \\
\text { Square }\end{array}$} & \multirow[b]{2}{*}{$\begin{array}{c}\text { Adjusted } \\
\text { R } \\
\text { Square }\end{array}$} & \multirow{2}{*}{$\begin{array}{c}\text { Std. } \\
\text { Error of } \\
\text { the } \\
\text { Estimate } \\
\end{array}$} & \multicolumn{5}{|c|}{ Change Statistics } & \multirow[b]{2}{*}{$\begin{array}{l}\text { Durbin- } \\
\text { Watson }\end{array}$} \\
\hline & & & & & $\begin{array}{c}\text { R } \\
\text { Square }\end{array}$ & $\begin{array}{c}\text { F } \\
\text { Change }\end{array}$ & df1 & df2 & $\begin{array}{c}\text { Sig. F } \\
\text { Change }\end{array}$ & \\
\hline 1 & 0,656 & 0,430 & 0,398 & 6,90623 & 0,430 & 13,227 & 2 & 35 & 0,000 & 1,810 \\
\hline
\end{tabular}

Masalah autokorelasi terjadi ketika adanya korelasi antara error term dari setiap variabel yang diamati. Hasil pengujian autokorelasi dengan melihat nilai Durbin Watson, didapatkan nilai sebesar 1,810. Tidak terjadi autokorelasi pada setiap variabel atau residual saling bebas, karena nilai Durbin Watson yang didapatkan terletak diantara nilai $\mathrm{D}_{\mathrm{U}}$ sebesar 1,5937 dan 4- $\mathrm{D}_{\mathrm{U}}$ sebesar 2,4063.

\section{Hasil Uji Parsial}

Sedangkan jika dilakukan uji secara parsial pada setiap variabel independen dengan variabel dependen, menghasilkan variabel HIV/AIDS memiliki pengaruh yang bermakna secara statistik terhadap kejadian Tuberkulosis di Provinsi Jawa Timur pada tahun 2015 karena nilai signifikansi atau $p$-value sebesar 0,000 (sig. $<0,05$ ). Sedangkan untuk variabel rumah sehat tidak mempengaruhi tingginya kejadian Tuberkulosis di Provinsi Jawa Timur pada tahun 2015 karena nilai signifikansi atau p-value sebesar 0,198 (sig.> 0,05).

\section{PEMBAHASAN}

Pengambilan data berlangsung dari tanggal 26 April sampai dengan 1 Mei 2018. Dari pendataan yang dilakukan oleh petugas Dinas Kesehatan Provinsi Jawa Timur bidang Pencegahan dan Pengendalian Penyakit didapatkan data jumlah kasus Tuberkulosis dan HIV/AIDS berdasarkan kabupaten/kota di Provinsi Jawa Timur tahun 2015, serta pada bidang Kesehatan Masyarakat didapatkan data jumlah rumah sehat berdasarkan kabupaten/kota di Provinsi Jawa Timur tahun 2015. Dari daftar tersebut kemudian dipilih daerah yang menjadi sampel. Karena dalam penelitian ini metode sampling menggunakan total populasi, maka seluruh kabupaten/kota tahun 2015 dipilih menjadi subjek penelitian.

Data Profil Kesehatan Provinsi Jawa Timur Tahun 2016 memiliki informasi yang cukup lengkap mengenai beberapa variabel seperti jumlah kasus Tuberkulosis, jumlah rumah sehat dan jumlah kasus HIV/AIDS.
Namun, terdapat data yang masih kosong pada beberapa kabupaten/kota, maka perlu dilakukan konfirmasi data kepada petugas yang bertanggungjawab terhadap pengolahan data di Dinas Kesehatan Provinsi Jawa Timur.

Analisis yang dilakukan pada penelitian ini menggunakan teknik uji multiple linear regression yang bertujuan agar dapat menghasilkan keputusan terkait apakah ada pengaruh dari variabel HIV/AIDS dan rumah sehat jika dilakukan secara serentak terhadap kejadian Tuberkulosis di Provinsi Jawa Timur. Status Tuberkulosis yang dimaksud adalah status semua jenis Tuberkulosis hasil pelaporan kasus dari Dinas Kesehatan pada setiap daerah di Provinsi Jawa Timur. sementara untuk veriabel independen yaitu kasus HIV/AIDS merupakan status HIV positif yang dilaporkan dari seluruh Dinas Kesehatan yang ada di wilayah Provinsi Jawa Timur, serta cakupan rumah sehat yang merupakan hasil pelaporan dari Dinas Kesehatan pada setiap daerah di Provinsi Jawa Timur.

Tabel 1 menunjukkan bahwa jumlah kasus HIV/AIDS dan cakupan rumah sehat mempengaruhi secara signifikan terhadap jumlah kejadian Tuberkulosis di Provinsi Jawa Timur pada tahun 2015, semakin banyak jumlah kasus HIV/AIDS dan cakupan rumah sehat, maka akan meningkatkan jumlah kasus Tuberkulosis di Provinsi Jawa Timur pada Tahun 2015. Hal ini sesuai dengan pernyataan Muchtar, et.al.. (2018) yakni bahwa penurunan kadar dan disfungsi sel CD4 yang progresif serta adanya kerusakan fungsi makrofag dan monosit pada penderita HIV menjadi predisposisi untuk terjadinya sakit TB.

Penelitian oleh Hazmi (2012) dengan tujuan untuk membandingkan jumlah kematian antara dua kelompok yakni kelompok penderita TB disertai infeksi HIV dan kelompok penderita TB yang tidak ada koinfeksi HIV, serta menganalisis korelasi antara status HIV dengan hasil pemeriksaan sputum BTA pada pasien Tuberkulosis Paru, dimana penelitian ini menggunakan desain studi kasus cross sectional terhadap 80 pasien 
dengan usia 12 sampai dengan 80 tahun yang melakukan pengobatan Tuberkulosis selama lebih dari 56 hari dan telah mendapatkan OAT dan juga memiliki hasil positif ataupun negatif dari uji sputum BTA, serta pada pasien dengan HIV/AIDS (ODHA) yang telah melakukan pemeriksaan HIV. Pasien tuberkulosis paru dengan koinfeksi HIV memiliki tingkat mortalitas yang lebih besar sebesar 38,6\% jika dibandingkan dengan pasien tuberkulosis paru yang tidak terinfeksi HIV yakni sebesar 4,8\%. Terdapat hubungan yang signifikan antara status HIV pasien tuberkulosis dengan hasil pemeriksaan sputum BTA. Risiko hasil uji BTA yang negatif pada pasien tuberkulosis disertai koinfeksi HIV 3,23 kali lebih besar daripada pasien tuberkulosis tanpa infeksi HIV. Dan terdapat hubungan yang signifikan antara status HIV pasien tuberkulosis terhadap tingkat mortalitas. Risiko terjadinya kematian pada penderita TB yang dinyatakan positif HIV lebih besar daripada penderita yang tidak disertai HIV yakni sebesar 12,41 kali.

Serta jika dilihat dari nilai koefisien korelasi parsial pada penelitian ini, apabila variabel HIV/AIDS dianggap konstan, variabel independen rumah sehat tidak memiliki hubungan dengan variabel dependen Tuberkulosis, dengan nilai signifikansi sebesar 0,198 .

Tidak adanya hubungan antara rumah sehat dengan terjadinya tuberkulosis ini disebabkan oleh kurang bervariasinya data karena mayoritas kabupaten/kota memiliki jumlah rumah sehat yang cukup tinggi serta syarat kesehatan yang harus dipenuhi untuk penilaian rumah sehat menurut Dinas Kesehatan Provinsi Jawa Timur (2016) itu sendiri bermacam-macam, dimana tidak semua indikator penilaian berkaitan dengan terjadinya kasus Tuberkulosis.

\section{SIMPULAN DAN SARAN}

\section{Simpulan}

Berdasarkan hasil penelitian yang telah dilakukan dapat ditarik kesimpulan bahwa variabel HIV/AIDS dan rumah sehat dapat mempengaruhi jumlah kejadian tuberkulosis di Provinsi Jawa Timur pada tahun 2015. Dimana hubungan yang dibentuk dari kedua variabel independen termasuk hubungan yang kuat dan arah hubungannya positif yang artinya jika jumlah HIV/AIDS dan rumah sehat mengalami peningkatan, jumlah tuberkulosis juga akan meningkat. Secara bersamaan kedua variabel independen dapat menjelaskan variabel dependen yakni tuberkulosis sebesar $43 \%$. Sedangkan jika dilihat dari koefisien korelasi parsial atau jika diuji secara parsial didapatkan hasil bahwa hanya HIV/AIDS yang memiliki hubungan yang signifikan dengan tuberkulosis, sedangkan rumah sehat tidak berpengaruh secara signifikan terhadap tuberkulosis.

\section{Saran}

Program penanggulangan kasus HIV/AIDS dan tubekulosis di Provinsi Jawa Timur perlu ditingkatkan oleh Pemerintah Provinsi Jawa Timur. Strategi yang dapat dilakukan adalah digencarkan penyuluhan atau pemberian informasi terkait penyakit HIV/AIDS dan tuberkulosis, pola penyebaran dan penularan penyakit dan cara pencegahan. Serta melakukan skrining HIV/AIDS secara rutin dan pemeriksaan rutin bagi pasien yang telah dinyatakan positif HIV/AIDS yang dilaksanakan oleh Dinas Kesehatan pada masing-masing daerah di Provinsi Jawa Timur. Pelaporan yang sistematis dan efisien terkait orang yang terinfeksi tuberkulosis perlu diperketat di setiap daerah untuk mencegah penyebaran virus yang terjadi dan segera mendapatkan pengobatan yang tepat dari tenaga kesehatan. Untuk penelitian selanjutnya, perlu mengkaji kembali data yang digunakan. Pemilihan data yang tepat untuk dikaitkan menjadi variabel independen diperlukan agar mengurangi risiko hasil yang tidak signifikan dan mengurangi risiko adanya variabel pengganggu.

\section{DAFTAR PUSTAKA}

Dinkes Provinsi Jawa Timur. 2016. Profil Kesehatan Provinsi Jawa Timur Tahun 2015. Surabaya: Dinas Kesehatan Provinsi Jawa Timur.

Ditjen PPM dan PL. 2002. Pedoman Teknis Penilaian Rumah Sehat. Jakarta: Departemen Kesehatan Republik Indonesia.

Hazmi, M.Z. 2012. Pengaruh Infeksi HIV terhadap Mortalitas Pasien TB Paru di Puskesmas Kampung Bali Jakarta Pusat Periode 2007-2011. Skripsi. Universitas Islam Negeri Syarif Hidayatullah Jakarta.

Karima, U.Q., Mondastri, K.S., Nuning, M.K. 2017. Prediktor Kejadian TB pada ODHA 
di Salah Satu RS Pemerintah Bogor, Tahun 2014-2016. Jurnal Epidemiologi Kesehatan Indonesia, [e-journal] 1 (2): pp. 25-34.

Keman, S. 2005. Perumahan dan Lingkungan Pemukiman. Jurnal Kesehatan Lingkungan, [e-journal] 2 (1): pp. 29-42.

Kemenkes RI. 2014. Pedoman Nasional Pengendalian Tuberkulosis. Jakarta: Kementerian Kesehatan Republik Indonesia.

Kemenkes RI. 2017. Profil Kesehatan Indonesia Tahun 2016. Jakarta: Kementerian Kesehatan Republik Indonesia.

Listyowati, R.D. 2011. Hubungan Rumah Sehat dengan Kejadian TB Paru di Kecamatan Karang Pilang Kota Surabaya. Skripsi. Universitas Airlangga.

Muchtar, N.H., Herman, D., Yulistini. 2018. Gambaran Faktor Risiko Timbulnya
Tuberkulosis Paru pada Pasien yang Berkunjung ke Unit DOTS RSUP Dr. M. Djamil Padang Tahun 2015. Jurnal Kesehatan Andalas, [e-journal] 7 (1): pp. 80-87.

Mukono, H.J. 2006. Prinsip Dasar Kesehatan Lingkungan. 2nd Ed. Surabaya: Airlangga University Press.

Najmah. 2016. Epidemiologi Penyakit Menular. Jakarta: Trans Info Media.

Peraturan Menteri Kesehatan Republik Indonesia Nomor 67 Tahun 2016 Tentang Penanggulangan Tuberkulosis. Jakarta: Kementerian Kesehatan Republik Indonesia.

Sarwoko. 2005. Dasar-Dasar Ekonometrika. 1st Ed. Yogyakarta: ANDI.

Sukarni, M. 1995. Kesehatan Keluarga dan Lingkungan. Yogyakarta: Kanisius. 